\title{
HAS THE FOOD AND AGRICULTURE SECTOR PLAYED ITS INTENDED ROLE IN SOCIO-ECONOMIC DEVELOPMENT OF SRI LANKA? AN EMPIRICAL INVESTIGATION
}

\author{
E. G. C. D. Bandara, U. K. Jayasinghe-Mudalige, J. M. M. Udugama, \\ A. M. C. M. Attanayake and J. C. Edirisinghe
}

\begin{abstract}
This study examines the economic research problem of whether the food and agriculture sector of Sri Lanka has played its intended role in the process of socio-economic development. The Myint Hypothesis was used to develop the analytical framework, which states that, as a country passes through the process of structural transformation (i.e. the agricultural share decreases overtime, while the Gross Domestic Production increases), its food and agriculture sector should "give a hand" for socio-economic development. by: (1) increasing the supply of food available for domestic consumption (food security); (2) releasing the agricultural labor force for specialized work in other sectors, including the manufacturing and services (intersectoral labor mobility); (3) increasing the supply of domestic savings from agriculture sector (capital formation), and (4) increasing the foreign exchange earnings through agricultural exports (agricultural trade). The outcome of analysis, which employed Distributed Lag Models in various functional forms for the data covering the period of 1970 to 2010, shows that the performance of the agriculture sector was fairly satisfactory to upkeep the levels of household food security, capital formation and foreign exchange earnings. It justifies, overall, respective government's efforts to safeguard agriculture sector by direct interventions, as it acts as the mainstay of livelihood for vast majority of people and has now come up to a situation where it can stand right with a "little help" extended by means of an incentive-based regulatory and facilitative policy framework.
\end{abstract}

Keywords: Food and agriculture, Socio-economic development, Structural transformation

\section{INTRODUCTION}

In ancient times, vast majority of fellow citizens in Sri Lanka were involved with cultivation of paddy and other field crops that can be used in domestic consumption. Therefore, at that time, the structure of Sri Lankan economy was based on agriculture. A number of distinct changes to the Sri Lankan economy were occurred since the western colonial powers governed the country starting from the Portuguese to the Dutch and finally the British, as well as the major rule changes of Sri Lankan governments in 1948 and 1977. Just after the independence in 1948, the manufacturing and services sectors have grown rapidly with compared to the food and agriculture sector and, the exportation value of industrial production was started to increase rapidly than agriculture exports. Due to those reasons, the structure of Sri Lankan economy has changed from agriculture-based to industrial-based. It is called the "structural transformation" of Sri Lankan economy.

Country's economic development can be measured in terms of the Gross Domestic Product (GDP). Agriculture share in GDP has been changed due to many reasons such as: (1) availability of major staple food crops for domestic consumption (e.g. paddy and other field crops); (2) domestic savings 
from agriculture; (3) economically active population engaged in agriculture, and (4) agricultural exports.

The agriculture share in GDP was changed from $28.3 \%$ in 1970 to $12.8 \%$ in 2010 (Central Bank of Sri Lanka, 1970 to 2010). Although, the paddy production was the basis of major staple food crop production during all those periods, plantation agriculture crops were given higher contribution to the agriculture exports. Domestic savings from agriculture has been increased during past four decades, for example, domestic savings from agriculture has been increased from 610.97 Rs. Million in 1970 to 2335.18 Rs. Million in 2010, which is about $382 \%$ increase. Although, the relative percentage of economically active population in agriculture sector has decreased, still, more than $70 \%$ of the 20.7 million people in the country make their livelihood, directly or indirectly, based on agriculture. Further, before 1970s, agriculture exports have accounted for more than $70 \%$ to $80 \%$ of total exports, while industrial exports were stagnated around $15 \%$. Just after the introducing open economic policies in later 1970 s, however, industrial exports have started to grow rapidly than agriculture exports (Central Bank of Sri Lanka, 1970 to 2010; Labour Force Survey, 2011).

In light of these, there are many unresolved problems exist in the context of food and agriculture sector in Sri Lanka. The major objective of this study was, therefore, to find out whether agriculture sector of Sri Lanka perform satisfactorily in past four decades $(1970$ - 2010) with respect to the key areas of food security, labour mobility, capital formation and agriculture trade with special focus on Hypotheses put forward by Myint (1977) with regard to role of agriculture in the process of structural transformation.

\section{METHODOLOGY}

\section{Theoretical Framework}

According to Myint (1977), in the process of structural transformation, the agriculture share of a given country to the GDP should be decreased; however, the contributions of agriculture sector to a number of key areas should be increased. In particular, the agriculture sector should be able to:

(1) Increase the supply of food available for domestic consumption (food security);

(2) Release the labor force engaged in agriculture related activities for specialized work in other sectors, i.e. industrial and services (inter sectoral labour mobility);

(3) Increase the supply of domestic savings from agriculture sector (capital formation), and

(4) Increase the supply of foreign exchange earned through agriculture exports (agricultural trade).

\section{Developing Hypotheses and Estimable Variables}

The following steps were used to develop estimable variables to test the hypotheses. First, to claim that food and agriculture sector in Sri Lanka has contributed to the economic development significantly by "securing food" for Sri Lankans, the "annual per capita production of paddy and other field crops for domestic consumption" (Pc_FC) $[\mathrm{kg} /$ person/year] was taken into account. Manioc, maize, chillies, red onion, ground nut, green gram, soya bean, potatoes, Bombay onion, kurakkan, sweet potato, gingerly, cowpea, and black gram were considered as other field crops. A positive sign $(+)$ was expected for this variable. 
Second, we can state that "the active labour force involved with the agriculture sector of a given year as a percentage to total economic active population in the same year" $\left(A g_{-} L F\right)$ [\%] should be decreased as these people should be released to work in other sectors (industrial and services). A negative sign (-) was expected for this variable.

Thirdly, it was hypothesized that "the stock of capital produced by the agriculture sector through domestic savings" $(A g D S) \quad[R s$. Million] should be increased over the years. The GDP from agriculture of a given year (GDPA) was multiplied by the Domestic Savings Ratio (DSR) of same year (i.e. GDPA $\times$ DSR) to derive this variable. A positive sign $(+)$ was expected for this variable.

Fourthly, "the foreign exchange earned through exporting of agricultural products" $($ Ag_EX) [Rs. Million in real terms] should be increased significantly over the time, although, as with the structural transformation, the ratio between this particular value and the total value of foreign exchange is to be decreased over the time. Key plantation agricultural crops (i.e. tea, rubber, and coconut) and major export agricultural crops (i.e. coffee, cocoa, cinnamon, pepper, cloves, and cardamoms) were considered. The expected value of this variable was also positive $(+)$.

\section{Econometric Specification of the Model}

The four explanatory variables explained above were used to specify the following empirical model:

$\mathrm{Ag} \_\mathrm{SH}_{\mathrm{i}}=\beta_{0}+\beta_{1}\left(\mathrm{Pc} \_\mathrm{FC}\right)_{\mathrm{i}}+\beta_{2}\left(\mathrm{Ag} \_\mathrm{LF}\right)_{\mathrm{i}}+\beta_{3}$ $\left(\mathrm{Ag} \_\mathrm{DS}\right)_{\mathrm{i}}+\beta_{4}\left(\mathrm{Ag} \_\mathrm{EX}\right)_{\mathrm{i}}+\varepsilon_{\mathrm{i}}$

Where:

Ag_SH $=$ Agriculture share in GDP

Pc_FC = Per capita availability of major staple food crops

Ag_LF = Agriculture labour force as a percentage of total labour force
Ag_DS = Agriculture domestic savings

Ag_EX = Agriculture exports

$\beta_{0}-\beta_{4}=$ Regression coefficient

$\varepsilon=$ Error term

$\mathrm{i}=\mathrm{i}^{\text {th }}$ year $(1970-2010)$

\section{Data Collection and Analysis}

The secondary data were collected from the annual reports of the Central Bank of Sri Lanka to cover the period of 1970 to 2010 and from several other sources published by the Department of Census and Statistics, including, Economic and Social Statistics of Sri Lanka (2009), National Accounts of Sri Lanka (2010), and Sri Lanka Labour Force Survey (2011).

Both descriptive and multivariate data analysis techniques including Multiple Linear Regression (Green, 2000) were used to analyze data. To find out the best fitted empirical model, the data were tested, separately, by specifying Linear, Reciprocal, Log-Log, Log-Linear, Linear-Log, and Log- Inverse models. All the above specifications were made up to their first lag. The Minitab (version 15) statistical software was used to estimate the coefficients of models. Fitted line plots were used to find out the relationship between agriculture share and each independent variable separately.

\section{RESULTS AND DISCUSSION}

The descriptive statistics of the variables used in the model are reported in Table 01.

\section{Agriculture Share}

The mean values of the GDP and GDP from agriculture (GDPA) during the period of 1970 to 2010 were 40,521 and 8,101 Rs. Million, respectively (Table 01). Figure 01 show that the value of GDP has increased with an increasing rate, but the rate of increase of the value of GDPA is relatively low. In 1970, agriculture share in GDP was $28.3 \%$ and it was $12.8 \%$ in 2010. The results emphasized that, the 
GDP has increased due to the performances of manufacturing and services sectors than agriculture sector in Sri Lanka.

\section{Food Security}

The total production of paddy and other field crops has been increased with a mean value of 3130 thousand metric tones during the past four decades. It was characterized by year-wise fluctuations. Per capita availability of major staple food crops for domestic consumption was shown a slightly positive trend (Figure 02 ). The mean value of this variable was $185.8 \mathrm{~kg} /$ head/year (Table 01). It reveals that per capita availability of food has shown considerably high amount but it was not comply with per capita requirement of food in each year.

\section{Labour Mobility}

The result shows that, there was a small negative trend occurred with respect to releasing of agriculture labour force to other sectors (manufacturing and services) during this period as a ratio of agriculture labour force to the total labour force (Figure 03). The mean value of this variable was $19.8 \%$ (Table 01 ).

\section{Capital Formation}

The value of domestic savings from agriculture sector has been increased with a positive trend and it can be noticed that this value was remained around 500 million Rs. since 1970 and it has reached up to 2300 million Rs. in 2010 (Figure 04). The mean value of this variable was 1231.2 million Rs. during the period of 1970 to 2010 (Table 01).

\section{Agricultural Trade}

The foreign exchange earned by exporting agricultural products has increased with an increasing rate, and it was much prominent since the open economic policies introduced in late 70s (Figure 5). For the entire period of 1970 to 2010 , the mean values of the total exports (i.e. agriculture + manufacturing + services) and agricultural exports were 231,053 million Rs. and 2958 million Rs. respectively (Table
01). In 1970, the value of agriculture exports was very small with compared to the value of agriculture exports in 2010 (Figure 05).

\section{Relationship between Agriculture Share and other Variables}

Fitted line plots were used to identify the relationship between agriculture share and each independent variable separately. Regression line and 95\% Confidence Interval (CI) were used to get the clear idea about the relationship between dependent and independent variables.

When Pc_FC increased, the Ag_SH in GDP has decreased with a slightly negative trend and small numbers of data were observed within the CI (Figure 06). It reveals that food security has shown slight correlation with the Ag_SH in past four decades. Further, when Ag_LF increased, the Ag_SH in GDP has also increased with a positive trend (Figure 07). This was happened not because of Ag_LF increase with the time, this happened due to the population of the country increased over the years. Moreover, when Ag_DS increased, the Ag_SH in GDP has decreased with a small negative trend (Figure 08).The Ag_DS were scattered in wide range during past four decades and the majority of the data were observed within the CI.

Furthermore, when consider about the relationship between $\mathrm{Ag}$ EX and $\mathrm{Ag}$ _SH in GDP, when Ag_EX increased, the Ag_SH in GDP has decreased with a small negative trend (Figure 09). This refers even the percentage of agricultural export increased with the time; it was not much contributed to increase the $\mathrm{Ag}$ $\mathrm{SH}$ in GDP because other sectors contributions to GDP were much higher than that. 
Table 01: Descriptive statistics of the variables used in the model

\begin{tabular}{cccc}
\hline Variable & Mean & $\begin{array}{c}\text { Standard } \\
\text { Deviation }(\text { SD) }\end{array}$ & $\begin{array}{c}\text { Coefficient of } \\
\text { Variation }(\mathbf{C V})\end{array}$ \\
\hline GDP & 40521 & 23847 & 58.9 \\
GDPA & 8101 & 2580 & 31.9 \\
Ag_SH & 23.4 & 6.2 & 26.7 \\
Pc_FC & 185.8 & 24.9 & 13.4 \\
Ag_LF & 19.9 & 2.2 & 10.9 \\
Ag_DS & 1231 & 531 & 43.2 \\
Ag_EX & 2958 & 760 & 25.7 \\
\hline
\end{tabular}
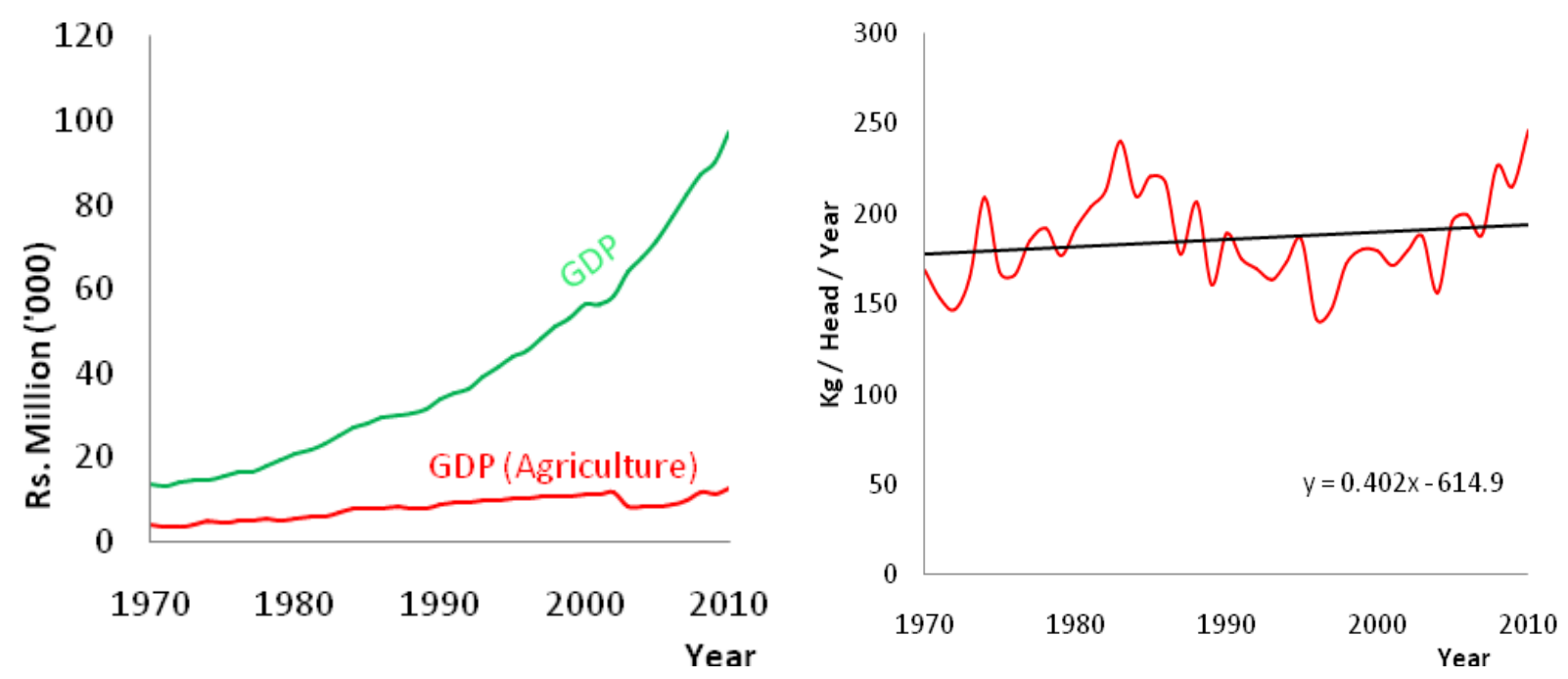

Figure 01: GDP from agriculture and the entire economy (1970 - 2010)

Figure 02: Per capita availability of major
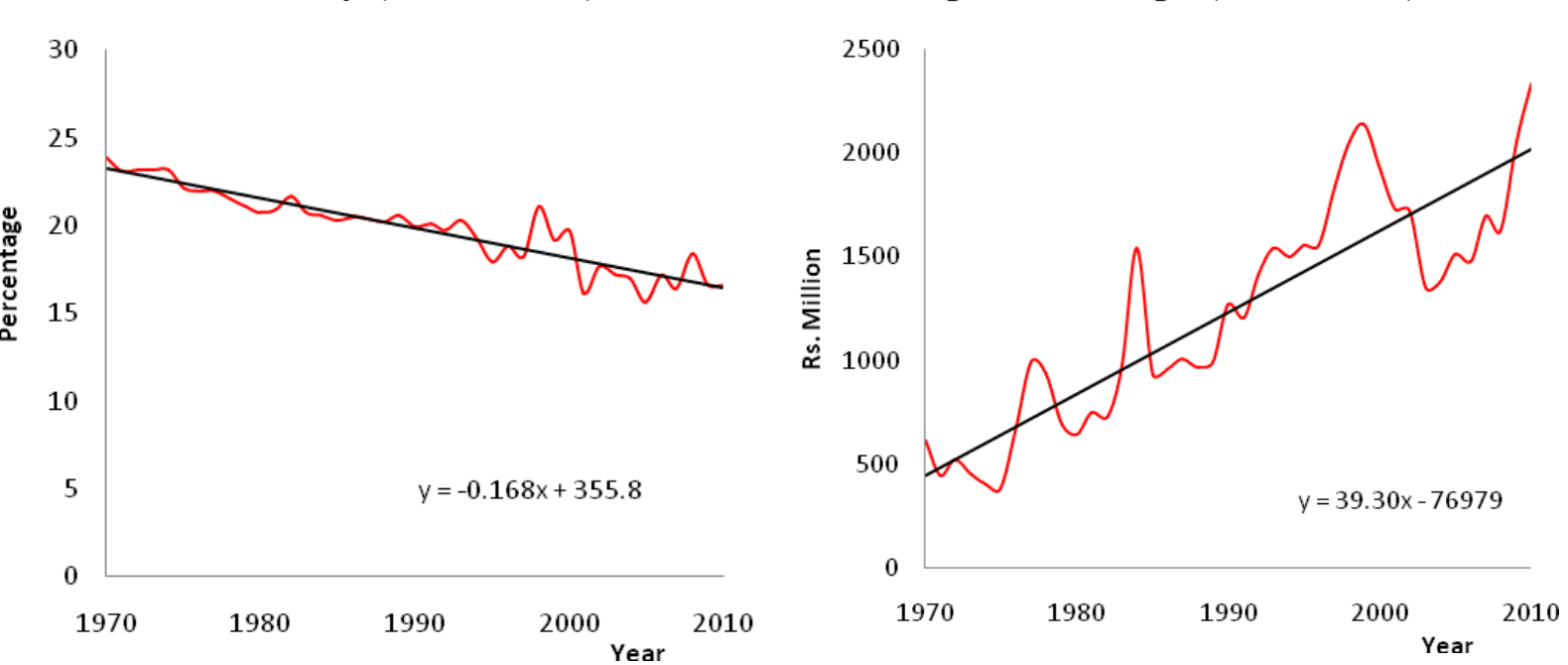

Figure 03: Percentage of agriculture labor Figure 04: Domestic savings from force to total labor force $(1970-2010)$ agriculture sector $(1970-\mathbf{2 0 1 0})$ 


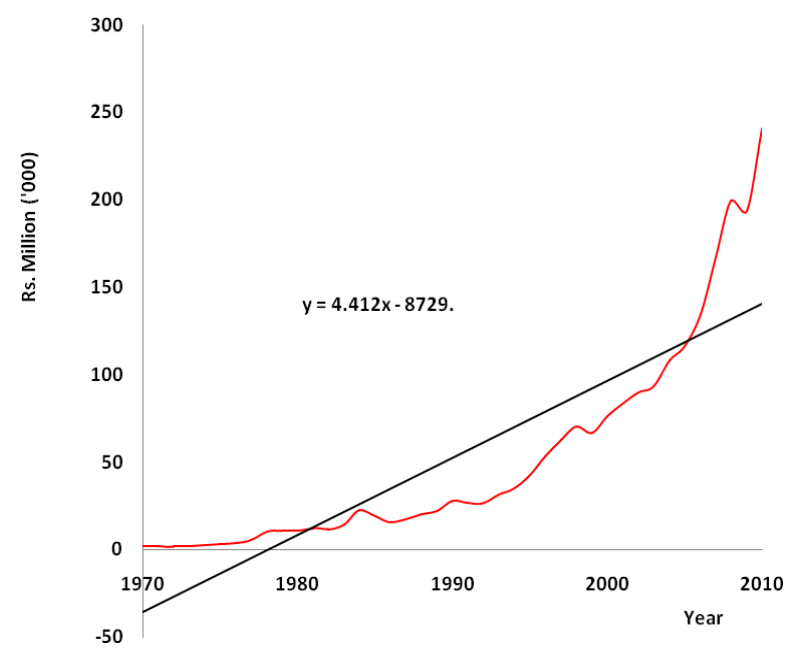

Figure 05: Value of agricultural exports in Sri Lanka (1970 - 2010)

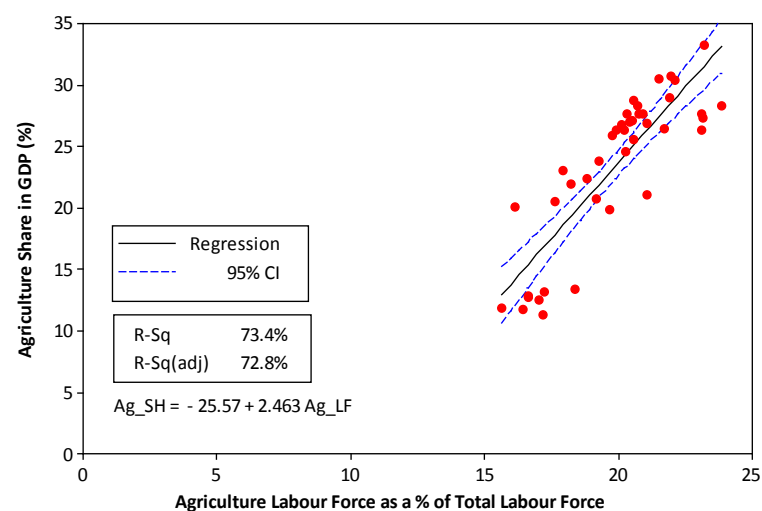

Figure 07: Ag SH verses Ag LF (1970 2010)

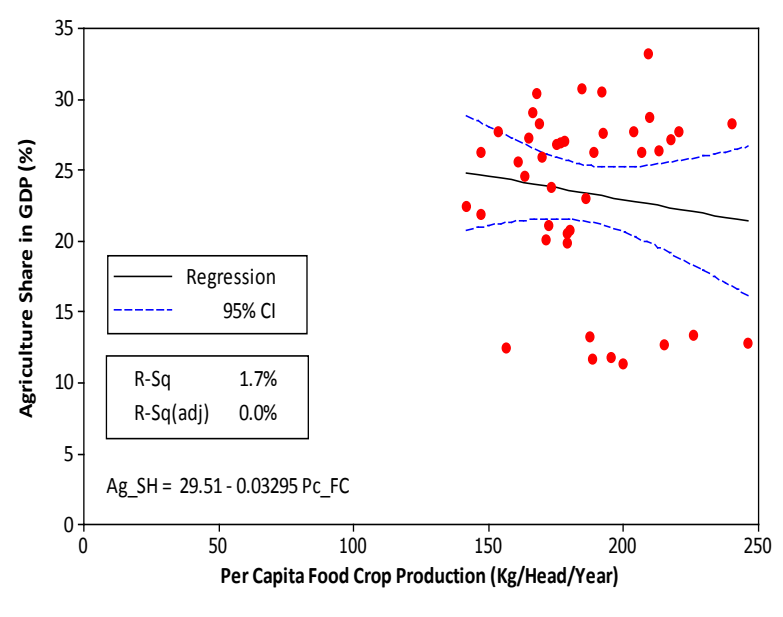

Figure 06:Ag_SH verses Pc_FC (1970 2010)

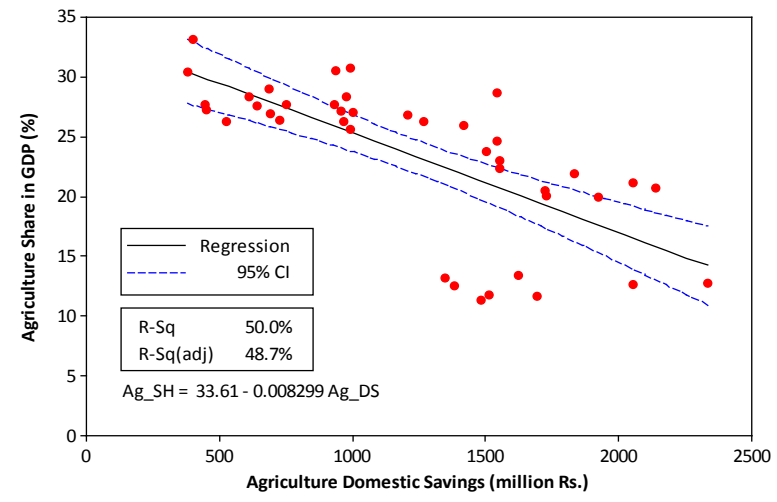

Figure 8: Ag_SH verses Ag_DS (1970 2010)

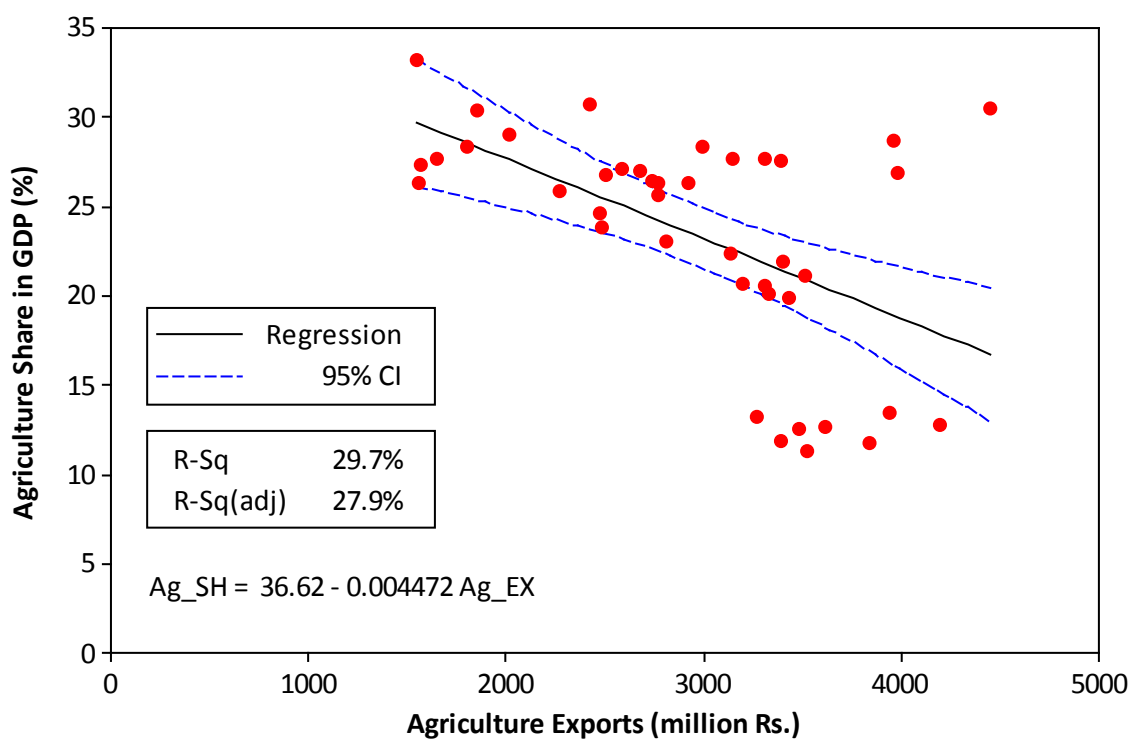

Figure 9: Ag_SH verses Ag_EX (1970 - 2010) 
Table 02:Estimates of variables

\begin{tabular}{lcc}
\hline \multicolumn{1}{c}{ Variable } & Parameter Estimate (P value) & Standard Error \\
\hline Pc_FC & 0.854 & 0.022 \\
$\left({\text { Pc_FC })_{\mathrm{t}-1}}_{1 / \mathrm{Ag} \_L F}\right.$ & 0.685 & 0.024 \\
$(1 / \mathrm{Ag} \text { _LF })_{\mathrm{t}-1}$ & $0.002^{*}$ & 153.8 \\
Ag_DS & $0.002^{*}$ & 152.2 \\
$(\text { Ag_DS })_{\mathrm{t}-1}$ & 0.967 & 0.002 \\
Ag_EX & 0.870 & 0.002 \\
$($ Ag_EX) & 0.447 & 0.001 \\
$\mathrm{H}-1$ & 0.558 & 0.001 \\
\hline
\end{tabular}

\section{The Best Fitting Empirical Model}

Finally, the best fitted empirical model was developed with respect to highest adjusted $\mathrm{R}^{2}$ values. The regression equation was found for that model as follows:

$$
\begin{aligned}
& \text { Ag_SH }=74.0+0.0041(\text { Pc_FC })+0.0098 \\
& \left(\mathrm{Pc} \_\mathrm{FC}\right)_{\mathrm{t}-1}-525\left(1 / \overline{\mathrm{A} g} \_ \text {LF }\right)-522 \\
& \left(1 / \mathrm{Ag}_{\mathrm{L}} \mathrm{LF}\right)_{\mathrm{t}-1}-0.00009\left(\mathrm{Ag} \_\mathrm{DS}\right)- \\
& 0.0004\left(\mathrm{Ag}_{-1} \mathrm{DS}\right)_{\mathrm{t}-1}+0.00087(\mathrm{Ag} \\
& \mathrm{EX})-0.00067\left(\mathrm{Ag} \_\mathrm{EX}_{\mathrm{t}-1}\right.
\end{aligned}
$$

According to best fitted empirical model, multiple regression analysis results were observed as adjusted $\mathrm{R}^{2}$ value of $80.5 \%$. It indicates that the variables Pc_FC, $\left(\mathrm{Pc} \_\mathrm{FC}\right)_{\mathrm{t}-1}$, $1 /$ Ag_LF, (1/Ag_LF) $)_{\mathrm{t}-1}$, Ag_DS, (Ag_DS $)_{\mathrm{t}-1}$, Ag_EX, and (Ag_EX) $)_{t-1}$ explain about $80.5 \%$ of the variation of Ag_SH in the model. The results suggest that two variables, namely $1 /$ Ag_LF and (1/Ag_LF) $)_{t-1}$ were significant at 0.05 probability level and, other variables were not significant at that level (Table 02).

\section{CONCLUSIONS}

Although, the outcome of analysis suggest that the food and agriculture sector in Sri Lanka was able to contribute satisfactorily towards the economic development of the country in a number of key areas, including food security, capital formation, and agricultural trade. Specially, care must be taken to release the excessive and unspecialized labour involved with agriculture to other sectors of the economy with an appropriate skill development, which was not taken place progressively in the past few decades. Agriculture sector performances were not bad in past four decades and results show that the agriculture share to the GDP has decreased due to the higher performance of manufacturing and services sectors than agriculture sector in Sri Lanka.

The results also stress that even agricultural share in GDP decrease with the time food security in the country was not in an unfavourable situation and that reveals the importance of providing continuous support and targeted incentives to the food and agriculture sector similar to what are "offered" to other two sectors. Any financial and physical supports (e.g. subsidies for paddy sector) that should be focused on individual sectors (farming, processing and distributing), and there is an urgent need for establishing economic and social institutions, both public and private in the marketing channel.

Finally, the policy makers must be aware of the individual sectors within agriculture. If that happens, the ultimate objective of "agriculture for economic development" would be able to achieve in the near future as the country move into the final stages of structural transformation. 


\section{REFERENCES}

Central Bank of Sri Lanka, Annual Reports (Various issues from 1970 to 2010).

Central Bank of Sri Lanka, Socio Economic Data Hand Books (Various issues from 1970 to 2010).

Department of Census and Statistics. (2009). Economic and Social Statistics of Sri Lanka. Colombo, Sri Lanka.

Department of Census and Statistics. (2010). National Accounts of Sri Lanka. Colombo, Sri Lanka.

Department of Census and Statistics. (2011). Sri Lanka Labour Force Survey. Colombo, Sri Lanka.

Green, W., (2000). Economic Analysis. Englewood Cliffs. NJ: Prentice Hall.

Myint, H., (1977). Agriculture and Economic Development in the Open Economy. World Bank, Washington D. C.

Myint, H., (1965). The Economics of Developing Countries. Praeger, New York. 